\section{Scientific journal}

\section{PHYSICAL AND MATHEMATICAL EDUCATION}

Has been issued since 2013.

Науковий журнал

ФІЗИКО-МАТЕМАТИЧНА ОСВІТА

Видається з 2013.
ISSN 2413-158X (online)

ISSN 2413-1571 (print)

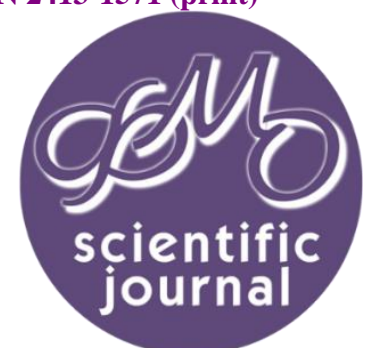

Черненко В.П. Формування інформатичної компетентності майбутніх вчителів інформатики в прочесі вивчення комп'ютерної математики. Фізико-математична освіта. 2021. Випуск 4(30). С. 6-12.

Chernenko $V$. The formation of informatics competency for future computer science teachers in the process of studying computer mathematics. Physical and Mathematical Education. 2021. Issue 4(30). P. 6-12.

DOI 10.31110/2413-1571-2021-030-4-001

UDC 378.047

V. Chernenko

Kremenchuk Mykhailo Ostrohradskyi National University, Ukraine varvara.chernenko@ukr.net

ORCID: https://orcid.org/0000-0002-2728-6876

\title{
THE FORMATION OF INFORMATICS COMPETENCY FOR FUTURE COMPUTER SCIENCE TEACHERS IN THE PROCESS OF STUDYING COMPUTER MATHEMATICS
}

\section{ABSTRACT}

\begin{abstract}
TRelevance and expediency of introduction of a training course of computer mathematics for students of "Secondary Education (Computer Science)" is caused by necessity of use of computer equipment with the corresponding software almost in all areas of human activity; the fact that computer mathematics is one of priority directions of research work both in the field of mathematical sciences, and in the field of computer science. Computer mathematics is a field of applied computer science in which problems of development, implementation and use of information technologies for solving mathematical problems are studied. The purpose of teaching computer mathematics is to study and use computer mathematics systems by students to solve applied problems; to master the conceptual and terminological base of modern computer science as a fundamental science; to master theoretical fundamentals of computer science related to formal systems, knowledge bases and models of their representation, models and algorithms of decision making.

Formulation of the problem. The study of computer mathematics by future computer science teachers and the use of modern systems of computer mathematics to solve applied problems, creates their system of professional competencies, in particular, informatics competencies in computer mathematics, informatics and mathematical competencies and skills to use modern information technology to analyze mathematical models of processes and phenomena from a variety of fields of knowledge and human activities.

Materials and methods. To achieve this goal, the following research methods were used: analysis of scientific and pedagogical literature on the research topic; analysis of curricula, work programs and manuals on the subject "Computer Mathematics"; empirical methods (questionnaire, conversation, pedagogical observation, modeling).

Results. This paper has built the model of building informatics competence within the professional competence of the future computer science teacher at the expense of integration of mathematical and information knowledge on the basis of mathematical modeling in environments of systems of computer mathematics, as these systems are an effective means of realization of inter-subject connections of computer science with other subjects of a natural-mathematical cycle.

Conclusions. The study of "Computer Mathematics" courses by future computer science teachers, using computer mathematics systems, contributes to the formation of components of the information competence system in the field of information, mathematical and computer modeling.

KEY WORDS: professional competence, informatics competence, computer science teacher, computer mathematics, systems of computer mathematics.

\section{INTRODUCTION}

Transition to a new generation of industry-specific standards of higher education through a competence-based approach is a necessary step on the way to reforming the education system in Ukraine, in particular, reforming the teaching of mathematics and computer science. Person-oriented education, introduction of innovations and communication technologies, creation of modern means of education is a priority in the educational process. Application of computer mathematics systems as a means of education through a competence-based approach creates conditions for bringing education closer to the needs and requirements of the labor market, further development of educational technologies and the education system as a whole. General regularities and theoretical bases for the application of computer mathematics systems in the educational process of training future computer science teachers are based on the implementation of interdisciplinary relations and the development of professional competencies of students studying mathematics and computer science.
\end{abstract}

(c) V. Chernenko, 2021. 
The purpose of the article. Development of methodical aspects of building informatics competencies of future computer science teachers in the process of studying computer mathematics.

An important trend of modern pedagogical education is the integration of traditional methodical systems of teaching various subjects with modern information and communication technologies through a competency-based approach to learning.

A. V. Khutorskoi, the developer of the theory and methods of competence-based education, has noted that the competencebased approach assumes that students do not master separate knowledge from each other, but master it in a complex way, and in its turn, allows applying the knowledge, skills and abilities gained in specific life situations (Khutorskoi, 2005). He defines competence as a set of interrelated qualities of a person (knowledge, skills, abilities, ways of activity), defined in relation to a certain range of subjects and processes and necessary to act in a qualitative and productive way in relation to them.

V. I. Baidenko proposes to understand the competence-based approach as a method of forming the results as signs of readiness of a student/graduate to demonstrate appropriate competence (Baidenko, 2006). Competence-based approach brings to the first position not awareness, but the ability to solve problems arising in the course of learning and understanding of natural and social phenomena, mastering modern techniques and technologies, relationships with other people, in everyday life during the performance of social roles, etc. The purpose of the competence-based approach is to organize the educational process aimed at acquisition of key competences.

O. M. Spirin believes that the competence-based approach becomes important in the design of professional training systems for computer science teachers, which should be used as a basis for the development of educational standards characteristics that reflect the qualitative results of the educational process in terms of professional competence (Spirin, 2007).

Thus, A. K. Markova believes that the content of the professional competence of a teacher is characterized by procedural and effective indicators and is defined as his or her ability and willingness to carry out personal professional activities (Markova, 1996). Possession of relevant competences allows acting independently and responsibly; the basis for conclusions on competence is the assessment of the final results of its activity; it is also a characteristic of an individual and is manifested in the results of its activity.

Professional competence is an integrative personal formation, formed on the basis of theoretical knowledge, practical skills, significant personal qualities and life experience (Evstegneyev \& Torbunov, 2003). All this determines the readiness of a computer science specialist to perform specific activities and ensures a high level of self-organization.

The main practical skills of a future computer science teacher include the following: algorithmization of various applied problems; programming of developed and typical algorithms; construction and study of mathematical models of various objects with the help of applied computer systems. Achieving these skills helps to fulfill one of the most important tasks for the computer science teacher - to promote the interest of students to study at the lessons of computer science.

\section{METHODS OF THE RESEARCH}

Theoretical methods have been applied for the purpose of analysis of academic literature on the subject; curricula, working programs and methodical manuals on Computer Mathematics. Empirical methods (questionnaires, conversations, lesson observation) have been used to determine the role of computer mathematics in the development of informatics competencies of future computer science teachers. Modeling was used to build a model for the formation of information competence of future teachers of computer science in the process of studying the discipline "Computer Mathematics".

\section{RESULTS OF RESEARCH}

The general structure of the system of professional competences of computer science specialists and their approximate classification is carried out in the paper (Zhaldak, Ramskyi \& Rafalska, 2009). Formation of a system of general professional and information competence of future computer science teachers is carried out during the following stages.

1. Basic stage (1-2 years). Formation of general professional competences in the course of studying the cycle of general training disciplines: algebra and geometry, mathematical analysis, mathematical logic, discrete mathematics, differential equations, probability theory and mathematical statistics.

2. Integration stage (1-3 years). Formation of informatics competencies in the course of studying the disciplines of professional training: basic programming, computer mathematics, algorithms and data structure, basic pedagogy, psychology.

3. Main stage (3-4 years). Formation of didactic and methodical competences in the course of studying the cycle of professional training disciplines: methods of teaching computer science, information technologies in education, coursework, pedagogical practice.

Informatics competence is an integrative education of a person, which integrates knowledge about the basic methods of computer science and information technologies, the ability to use available knowledge to solve applied problems, skills necessary to effectively use modern means of information and computer technologies to solve problems in professional activity and everyday life (Holovan, 2007).

Informatics competence can be characterized through the effectiveness of activities using modern information and communication technologies, which means the effective application of knowledge and skills to solve existing or human problems. (Baranovska, 2014).

The study of computer mathematics and the use of modern systems of computer mathematics (CMSs) contribute to the formation in future computer science teachers of general skills of setting and solving problems with the help of a computer, the use of it as a tool for organizing search and research activities, opens up new opportunities for educational interaction between students and teachers, and gives each student the opportunity to maximize their intellectual potential.

From the point of view of competence-based approach, the purpose of studying the Computer Mathematics is the formation in future computer science teachers of a high level of competence in the field of computer science, that is, informatics competence - the ability to meet their own individual needs and social requirements for the building of professionally specialized competencies in the field of computer science. 
The model of building informatics competencies of future computer science teachers in the course of studying computer mathematics is presented in Fig. 1.

In the course of studying computer mathematics, future computer science teachers explore the possibilities of using modern information and communication technologies to study various processes and phenomena based on mathematical modeling and the application of theories and methods of studying such models.

In the course of our research, a system of applied problems from computer mathematics has been created, aimed at the formation of informatics competencies of future computer science teachers.

To support the study of algebra, geometry and mathematical analysis within the Computer Mathematics discipline, specialists of the Department of Computer Science and Higher Mathematics of the Kremenchuk Mykhailo Ostrohradskyi National University propose to use a universal mathematical software Maple, which contains a fairly wide range of functions and computational tools. Maple can perform complex operations: symbolic computations (finding derivatives, integrals, boundaries, transformation of expressions, etc.); multiple operations (solving equations, inequalities, equation systems, interpolation tasks, optimization, etc.). Graphical tools for processing the results of calculations in Maple are among the best among other CMSs.

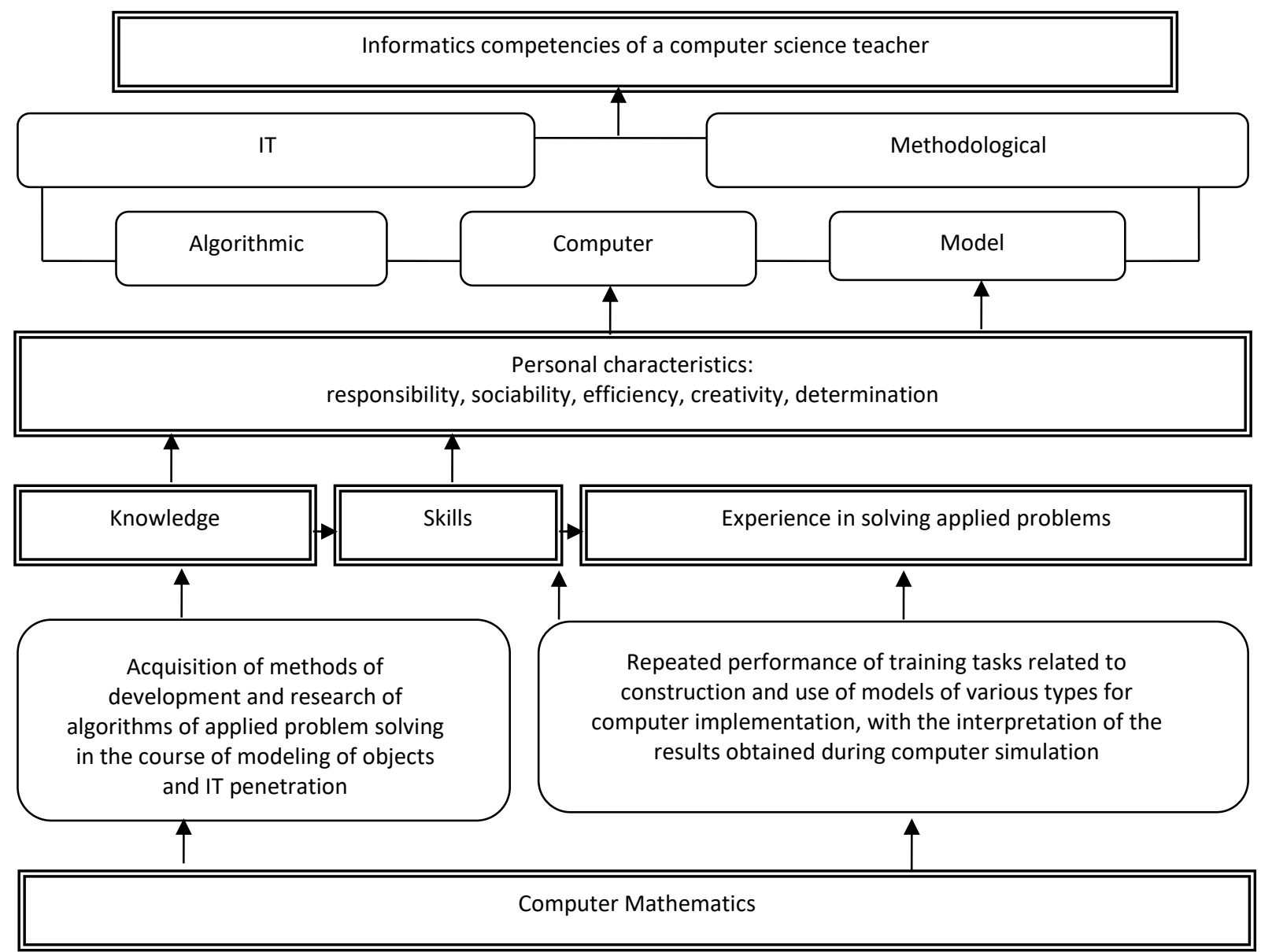

Fig. 1. Model of informatics competence building for computer science teachers

For example, in laboratory classes in Computer Mathematics, informatics competencies can be built in three stages (Kobylnyk, 2009).

1. Preparatory stage: formation of generalized subject skills. Students are offered theoretical assignments, execution of which will allow them to acquire knowledge, skills and abilities that will make it possible for them to solve problems of the highest level at the next stages.

2. Main stage: development of research and project skills. At this stage, students are offered practical problems.

3. Reinforcement stage: development of skills of using CMS for solving applied problems.

Let us give a fragment of a laboratory lesson in Computer Mathematics on the topic 'Solution of linear equation systems by Gauss method'.

In the course of studying the systems of linear algebraic equations (SLAE), two aspects can be distinguished: theoretical (the concept of SLAE, their compatibility, decoupling, methods of solution, study of the number of solutions, checking solutions, etc.) and applied (development of SLAE as a mathematical model of text problems and solution of such models by CMS methods).

At the preparatory stage, students are offered tasks and theoretical questions: what is a SLAE; what is a SLAE called a consistent/inconsistent, defined/undefined SLAE; which SLAE can be solved by the Gauss method; describe the algorithm of the Gauss method; build a block diagram of the Gauss method algorithm.

At the main stage, students are offered practical problems and exercises, and after familiarizing themselves with the main functions of the Maple system for SLAE solution, they are offered to solve the same system with the help of the Maple system. 
Example 1. Solve SLAE using the Gauss method.

$$
\left\{\begin{array}{l}
5 x-3 y+z=14 \\
x+y+z=2 \\
-x-2 y+2 z=2 .
\end{array}\right.
$$

Solution. First of all, it is necessary to solve this system in a notebook by performing the steps of the Gaussian method algorithm. Next, it is necessary to solve the system using Maple in two ways: the first way is to check the manual method directly, and the second way is to use the built-in Maple functions. Figures 2 and 3 show screenshots of the SLAE solution in the Maple system in various ways.

$$
\begin{aligned}
& \begin{array}{l}
{[>\text { restart :\# I way }} \\
\square l 1:=5 \cdot x-3 \cdot y+z=14: \# \text { introduce the first equation of the system }
\end{array} \\
& {[>12:=x+y+z=2 \text { :\# introduce the second equation of the system }} \\
& >13:=-x-2 \cdot y+2 \cdot z=2: \text { \# introduce the third equation of the system } \\
& >l 2:=l 2+l 3 ; l 3:=\frac{l 1}{5}+l 3 ; l 2:=l 3 \cdot\left(-\frac{5}{13}\right)+l 2 \text {; } \\
& \text { \# perform the forward course of the Gauss method } \\
& 12:=-y+3 z=4 \\
& l 3:=-\frac{13}{5} y+\frac{11}{5} z=\frac{24}{5} \\
& 12:=\frac{28}{13} z=\frac{28}{13} \\
& >z:=\operatorname{solve}(l 2) ; y:=\text { solve }(13) ; x:=\text { solve }(l 1) \text {; } \\
& \text { \# perform the backward course of the Gauss method } \\
& z:=1 \\
& \begin{aligned}
y & :=-1 \\
x & :=2
\end{aligned}
\end{aligned}
$$

Fig. 2. Checking the manual way of solving SLAE in the Maple system

$$
\begin{aligned}
& \text { [> restart: : II way } \\
& >\text { with (LinearAlgebra) :\# connect Linear Algebra package } \\
& >A:=\langle\langle 5,1,-1\rangle|\langle-3,1,-2\rangle|\langle 1,1,2\rangle \mid\langle 14,2,2\rangle\rangle ; \# \text { create an extended matrix of coefficients } \\
& A:=\left[\begin{array}{rrrr}
5 & -3 & 1 & 14 \\
1 & 1 & 1 & 2 \\
-1 & -2 & 2 & 2
\end{array}\right] \\
& \begin{array}{llll}
-1 & -2 & 2 & 2
\end{array} \\
& >\text { Ag }:=\text { GaussianElimination }(A) \text {; forward course: reducing the system to a triangular view } \\
& A g:=\left[\begin{array}{cccc}
5 & -3 & 1 & 14 \\
0 & \frac{8}{5} & \frac{4}{5} & -\frac{4}{5} \\
0 & 0 & \frac{7}{2} & \frac{7}{2}
\end{array}\right] \\
& >_{z}:=\operatorname{Ag}[3,4] / A g[3,3] \text {; \# backward course: search for unknowns }
\end{aligned}
$$

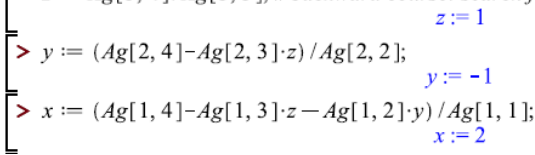

Fig.3. Using Maple's built-in features to solve SLAE

Example 2. Two plants supply cars for two auto farms, the needs of which are 200 and 300 cars, respectively. The first plant has produced 350 cars, the second one -150 cars. Table 1 shows the costs of transporting cars to each of the farms. The total minimum cost of transportation is 7,950 monetary units. Find a transportation plan for the vehicles.

\begin{tabular}{|c|c|c|}
\hline \multirow{2}{*}{ Plant } & \multicolumn{2}{|c|}{ Costs of transportation to auto farms } \\
\cline { 2 - 3 } & 1 & 2 \\
\hline 1 & 15 & 20 \\
\hline 2 & 8 & 25 \\
\hline
\end{tabular}

Table 1

Solution

1. Let $x_{i j}$ be the number of cars supplied from the ith plant to the $j$ th auto farm. Let us build a mathematical model of this problem.

$$
\left\{\begin{array}{l}
x_{11}+x_{12}=350 \\
x_{21}+x_{22}=150 \\
x_{11}+x_{21}=200 \\
x_{12}+x_{22}=300 \\
15 x_{11}+20 x_{12}+8 x_{21}+25 x_{22}=7950
\end{array}\right.
$$

2. We solve this problem using the Gaussian method in the Maple system in the second way (Fig. 5). 


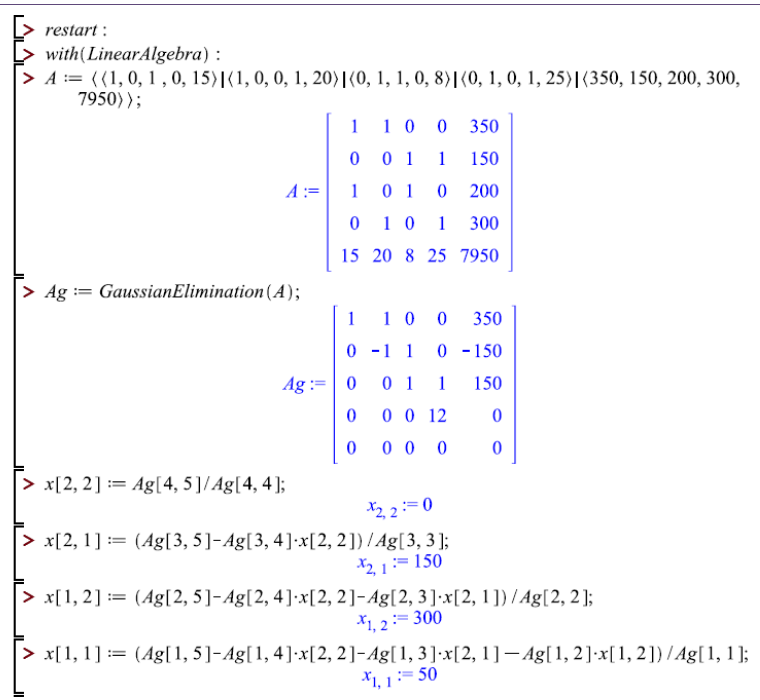

Fig. 4. Solution of an applied problem in the Maple system

Consequently, computer mathematics builds integrative knowledge of mathematics and computer science as knowledge of a higher order in comparison with the knowledge of isolated subjects, creates more opportunities for individualization of tasks and independent activity of students. CMSs can be used as information and communication technologies for teaching computer science and mathematics in both higher and secondary schools.

The use of CMSs, in particular Maple and MathCAD, to solve applied problems in the course of studying Computer Mathematics contributes to the intensification of learning and cognitive activities of students and increases the mathematical and information culture of future computer science teachers.

\section{DISCUSSION}

In the process of teaching the discipline "Computer Mathematics", which is studied by students majoring in "Secondary Education (Computer Science)", the theoretical and applied aspects of the use of SCM are combined. In the process of teaching this course, it is necessary to develop students' ability to effectively use SCM in their future activities, as well as to promote the development of skills to master new software, which corresponds to the ideas of the competence approach in education. These findings correlate with the study (Shyshkina\&Kogut, 2014), in which the authors argue that with the use of SCM, as well as ICT tools based on cloud, technologies can be created and modernized in a modern high-tech learning environment, which will increase the level of fundamentalization of ICT learning, improve the quality of information education and information literacy of students. The information competence of a future computer science teacher should be understood as a dynamic system of cognitive, activity, motivational, value-reflexive, emotional-volitional and heuristic personality qualities formed at the appropriate level of higher education, necessary for effective professional activity in information and educational space. (Matsekha, 2018). If you consider a model for the formation of informatics competence of future computer science teachers in the process of training, which includes implementation of sequentially structured components: target, normative, theoreticalmethodological, technological, methodological, organizational and functional, evaluative and effective blocks, (Petrenko\&Petrenko, 2020), then the model built in the work refers to the methodological unit of formation of information competence of future teachers of computer science.

One of the ways to improve the quality of professional training of future teachers of computer science, is the introduction into the educational process of computer-oriented methodological systems for teaching computer mathematics, combining theoretical and applied aspects of computer science, which strengthens the fundamentals of computer science education. activities of students, the disclosure of their creative potential, increasing the role of independent work in educational activities, the formation of scientific worldview, the system of professional and cultural competencies, intellectual development, the formation of young people as highly qualified and highly educated professionals (Efymenko, 2004).

\section{CONCLUSIONS AND PERSPECTIVES FOR A FURTHER RESEARCH}

Based on the analysis of academic and methodical literature on the subject of research, the structure of informatics competence as a component of the professional competence of future computer science teachers has been revealed, which includes the methodological, informational-technology, model, algorithmic, computer components. A model for the formation of informatics competence in future computer science teachers in the process of studying computer mathematics has been built and is shown on the example of the Maple computer mathematics system, how its use in the educational process helps to increase the level of informatics education of future computer science teachers.

It has been substantiated that each of the stages of the formation of informatics competencies involves the assimilation of a certain level of knowledge, the formation of skills and experience and work with computer mathematics systems, subject to the introduction of computer-oriented forms of organization of the educational process, traditional and innovative teaching methods and tools. It has been proved that a high level of formation of informatics competence can be achieved in the process of an individual and productive process of solving applied problems using computer mathematics systems. Based on this, a system of applied problems for the Computer Mathematics has been developed in order to form the components of informatics competence.

The study does not purport to be the complete solution to the difficulties involved in developing informatics competences for future computer science teachers. Further research, in our opinion, requires such issues as the improvement of computer- 
oriented methodological systems for teaching computer mathematics to future computer science teachers and the creation of an educational-methodical complex for Computer Mathematics for the successful mastery of related academic disciplines.

\section{References}

1. Baidenko, V. I. (2006). Vyyavleniye sostava kompetentsiy vypusknikov vuzov kak neobkhodimyy etap proyektirovaniya GOS VPO novogo pokoleniya: metod. posobiye [Identification of the composition of competencies of university graduates as a necessary stage in the design of State Educational Standard of higher vocational education of a new generation: a methodological guide], Moscow, Research Center for problems of quality training, 54 p. [in Russian].

2. Baranovska, V.M. (2014). Sutnist' poniattia "systema informatychnykh kompetentnostei» [The essence of the notion of «system of informational competencies»]. Naukovyi chasopys NPU imeni M.P. Drahomanova. Seriia № 2. Kom'iuterno-oriientovani systemy navchannia-Scientific journal of NPU named after M. P. Dragomanov. Series No 2. Computer-oriented learning systems, 14(21), 48-59. Retrieved from http://nbuv.gov.ua/UJRN/Nchnpu_2_2014_14_9 [in Ukrainian].

3. Evstegneyev, V.V. \& Torbunov, S.S. (2003). Integratsiya fundamental'nogo i spetsial'nogo znaniy v podgotovke inzhenernykh kadrov [Integration of Fundamental and Special Knowledge in Training of Engineering Personnel]. Alma Mater, 11, 14-16. [in Russian].

4. Efymenko, V.V. (2014). Osoblyvosti navchannia komp'iuternoi matematyky maybutnikh uchyteliv informatyky [Features of teaching computer mathematics to future computer science teachers]. Naukovyi chasopys NPU imeni M.P. Drahomanova. Seriia № 2. Komp'iuterno-oriientovani systemy navchannia - Scientific journal of NPU named after M. P. Dragomanov. Series No 2. Computer-oriented learning systems,, 21(14), 130-137. Retrieved from http://nbuv.gov.ua/UJRN/Nchnpu_2_2014_14_23 [in Ukrainian].

5. Holovan, M.S. (2007). Informatychna kompetentnist': sutnist', struktura ta stanovlennia [Informatics Competence: Essence, Structure and Formation]. Informatyka ta informatsiini tekhnolohii v navchal'nykh zakladakh - Computer science and information technology in schools, 4, 62-69. Retrieved from http://dspace.uabs.edu.ua/jspui/handle/123456789/112. [in Ukrainian].

6. Khutorskoy, A.V. (2005). Tekhnologiya proyektirovaniya klyuchevykh i predmetnykh kompetentsiy [Technology of Designing Key and Subject Competences]. Internet-zhurnal «Eydos» - Internet magazine Eidos, 12. Retrieved from http://eidos.ru/journal/2005/1212.htm. [in Russian].

7. Kobylnyk, T. P. (2009). Metodychna systema navchannia matematychnoi informatyky u pedahohichnomu universyteti: dys. ... kand. ped. nauk: 13.00.02 [Methodical system of teaching mathematical informatics at the pedagogical university: dis. ... cand. ped. science: 13.00.02], Kyiv, NPU named after M.P. Dragomanov, 256 p.

8. Markova, A.K. (1996). Psikhologiy professionalizma [Psychology of Professionalism], Mockow, Znaniye, 308 p. [in Russian].

9. Matsekha. V. (2018). Struktura i zmist informatychnoyi kompetentnosti pedahoha profesiynoho navchannia komp'yuternoho profiliu [The structure and content of the informational competence of the teacher of professional training of computer profile]. Obrii-Horizons, 1(46), 62-65. [in Ukrainian].

10. Petrenko, S. \& Petrenko, L. (2020). Model' formuvannia informatychnoi kompetentnosti maibutnikh uchyteliv informatyky v protsesi fakhovoi pidhotovky [A model for the formation of ICT competence of future computer science teachers in the process of vocational training]. Pedahohichni nauky: teoriia, istoriia, innovatsiini tekhnolohii - Pedagogical sciences: theory, history, innovative technologies, 2(96), 154-164. [in Ukrainian].

11. Shyshkina, M.P. \& Kogut U.P. (2014). Metodychni aspekty vykorystannya systemy Maxima iak zasobu fundamentalizatsii navchannia bakalavriv informatyky [The methodical aspects of maxima using as a tool for fundamental training of bachelors of computer science]. Informatsiini tekhnolohii v osviti - Information Technologies in Education, 20, 74-83. DOI:10.14308/ITE000498. [in Ukrainian].

12. Spirin, O.M. (2007). Kompetentnisnyy pidkhid u proektuvanni profesiinoi pidhotovky vchytelia informatyky [Competence-based approach in the design of computer science teacher training]. Naukovyi chasopys NPU imeni M.P. Drahomanova. Seriia 5. Pedahohichni nauky: realii i perspektyvy - Scientific journal of NPU named after M. P. Dragomanov. Series No 5. Pedagogical sciences: realities and prospects, Issue 7, 150-156. [in Ukrainian].

13. Spirin, O.M. (2007). Teoretychni ta metodychni zasady profesiynoi pidhotovky maibutnikh uchyteliv informatyky za kredytnomodul'noiu systemoiu : monohrafiia / za nauk. red. akad. M.I. Zhaldaka [Theoretical and methodological foundations of professional training of future computer science teachers on the credit-modular system: monograph / Under the scientific editorship of academician M.I. Zhaldak], Zhytomyr, Zhytomyr State University named after I. Franko, 300 p. [in Ukrainian].

14. Zhaldak, M.I., Ramskyi, lu.S., Rafalska, M.V. (2009). Model' systemy sotsial'no-profesiynykh kompetentnostei vchytelia informatyky [Model of the system of social and professional competencies of a computer science Teacher]. Naukovyi chasopys NPU imeni M.P. Drahomanova. Seriia № 2. Komp'iuterno-oriientovani systemy navchannia - Scientific journal of NPU named after M. P. Dragomanov. Series No 2. Computer-oriented learning systems, 7(14). 3-18. [in Ukrainian].

\section{ФОРМУВАННЯ ІНФОРМАТИЧНОЇ КОМПЕТЕНТНОСТІ МАЙБУТНІХ ВЧИТЕЛІВ ІНФОРМАТИКИ В ПРОЦЕСІ ВИВЧЕННЯ КОМП'ЮТЕРНОЇ МАТЕМАТИКИ В.П. Черненко}

Кременчуцький національний університет імені Михайла Остроградського, Україна

Анотація. Актуальність і доцільність впровадження навчального курсу комп'ютерної математики для студентів спеціальності «Середня освіта (інформатика)» обумовлена необхідністю використання комп'ютерної техніки з відповідним програмним забезпеченням практично у всі сфери діяльності людей; тим, що комп'ютерна математика є одним з пріоритетних напрямів науково-дослідної роботи як у галузях математичних наук, так $і$ в галузях інформатики. Комп'ютерна математика - це напрям прикладної інформатики, в якій вивчають проблеми розробки, впровадження та використання інформаційних технологій для розв'язання математичних задач. Мета навчання комп'ютерній математиці-вивчення та використання студентами систем комп'ютерної математики для розв'язання прикладних задач; оволодіння студентами 
понятійно-термінологічною базою сучасної інформатики як фундаментальної науки; засвоєння студентами теоретичних основ інформатики, пов'язаних з формальними системами, базами знань та моделями їх подання, моделями та алгоритмами прийняття рішень.

Формулювання проблеми. Вивчення комп'ютерної математики майбутніми вчителями інформатики та використанням сучасних систем комп'ютерної математики для розв'язування прикладних задач фрормує у них систему професійних компетентностей, зокрема інформатичних компетентностей, інформатично-математичні знання та вміння використовувати сучасні інформаційні технології для аналізу математичних моделей процесів і явищ з найрізноманітніших галузей знань і діяльності людей.

Матеріали і методи. Для реалізації поставленої мети було використано такі методи дослідження: аналіз науково-педагогічної літератури з теми дослідження; аналіз навчальних планів, робочих програм і методичних посібників з навчальної дисципліни «Комп'ютерна математика»; емпіричні методи (анкетування, бесіда, педагогічне спостереження, моделювання).

Результати. Уданій роботі побудована модель формування інформатичної компетентності як складової професійної компетентності майбутнього вчителя інформатики за рахунок інтеграції математичних та інформатичних знань на основі математичного моделювання у середовищах систем комп'ютерної математики, так як ці системи є ефективним засобом реалізації міжпредметних зв'язків інформатики з іншими предметами природничо-математичного циклу.

Висновки. Вивчення навчального курсу "Комп'ютерна математика" майбутніми вчителями інформатики з використання систем комп'ютерної математики сприяє формуванню компонентів системи інформатичної компетентності у галузі інформаційного, математичного і комп'ютерного моделювання.

Ключові слова: професійна компетентність, інформатична компетентність, вчитель інформатики, комп'ютерна математика, системи комп'ютерної математики.

\section{(c)) EY-NC-SA}

This work is licensed under Creative Commons Attribution-NonCommercial-ShareAlike 4.0 International License. 